\title{
Evaluation of the Microbiological Quality of Palm Wine Sold in Djèrègbé on the Cotonou-Porto-Novo Road
}

C. K. C. Tchekessi ${ }^{1 *}$, A. K. E. Hilla ${ }^{1}$, A. M. A. Djogbe ${ }^{1}$, S. A. P. Sachi ${ }^{1}$, S. Kouglenou ${ }^{2}$, A. H. Loko ${ }^{1}$, S. B. J. Banon ${ }^{1}$, T. M. R. Bleoussi ${ }^{1}$, T. K. Assogba ${ }^{1}$ and P. I. Bokossa Yaou ${ }^{1}$

${ }^{1}$ Food Safety Research Unit (URSSA), Laboratory of Microbiology and Food Technology (LA.MI.T.A.), Department of Plant Biology, Faculty of Science and Technology (FAST) of the University of Abomey-Calavi (UAC), 04 BP 1107 Cotonou; Benin

${ }^{2}$ Section of Hygiene, Water and Food (SHEA), National Public Health Laboratory, Ministry of Health of Benin, Cotonou, Benin

*Corresponding author

\section{A B S T R A C T}

\section{Keywords}

Palm wine, microbiological quality, Djèrègbé, Benin

\section{Article Info}

Accepted:

25 September 2020

Available Online:

10 October 2020
Palm wine is a sweet and more or less fermented drink obtained from the sap of the palm oil. This wine is a favorable environment for the multiplication of microorganisms which can sometimes be the basis of food poisoning. The aim of this study is to control the microbiological quality of palm wine sold on the Cotonou-Porto-Novo road precisely in Djèrègbé. After sampling palmwine, microbiological analyses of these samples were carried out in the laboratory. The results showed that the palm wine samples contained yeast and lactic bacteria. The presence at high loads of certain microorganisms such as mesophilic aerobic germs, molds, coliforms, Escherichia coli, positive coagulase Staphylococci, and sulfito-reducing anaerobic bacteria was also observed in all products. The microbiological quality of these drinks is therefore not satisfactory. Consequently, the wines analyzed are not in conformity with the normative criteria. Thus, for proper monitoring of hygiene rules, a quality control system must be set up during the extraction, packaging and sealing of palm wine in order to enable people to consume a product of satisfactory microbiological quality.

\section{Introduction}

Thousands of plants are used daily in Africa, both for nutritional or medicinal reasons and for the search for additional income. Among these plants is the oil palm (Elaeis guineensis), a tree-like plant that can reach 20 to 30 meters in height, native to the Gulf of Guinea and belonging to the Arecaceae family (Adande et al., 2010). The palm oil is cultivated for its fruits and occupies an important place because the populations not only derive several food products (palm and palm kernel oil, seeds, etc..) but also a drink much appreciated by all: "palm wine" (Behït et al., 2002), which after distillation gives the palm alcohol locally called "Sodabi" in Benin. Palm wine, obtained from the sap of the palm 
oil, is a natural drink sweetened at harvest and alcoholic after spontaneous fermentation. It is a popular traditional drink in Africa, in most tropical regions (Dornier et al., 1993). Palm wine is extracted from several species of palm but in Benin it is derived mainly from African palm oil (Elaeis guineensis Jacq) and plays an important role in the diet and economy of rural families (Boniet al., 1994; Dessouassi, 2013). Far from being the only pleasure, the consumption of palm wine is a significant partof the life of rural populations during lean periods, ceremonies and during intense field work (Adande et al., 2010).

Once harvested, palm wine is fresh, white in color, milky in consistency and has a sweet and mild flavour. Its sugar content varies between 10 and 12\% (Dornier et al., 1993). A few hours after the wine is harvested, we notice that fermentation increases, the wine becomes sparkling, strong, sometimes bitter and takes on a darker hue (Dornier et al., 1993). The consumption of palm wine by populations has increased in Benin in recent years (Dessouassi, 2013). However, it is common to observe ignorance and lack of mastery of hygiene rules during the production and sale of palm wine, which does not guarantee the hygienic quality of the product. Indeed, the actors of the sector (producers and sellers) work in unhealthy conditions, thus constituting huge sources of contamination of wine by microorganisms. The objective of this study is to evaluate the microbiological quality of palm wine sold in Djèrègbé.

\section{Study framework}

The Food Safety Research Unit (URSSA) and the Hygiene, Section of Hygiene Water and Food (SHEA) of the National Public Health Laboratory of the Ministry of Health of Benin served as the framework for the work.

\section{Materials and Methods}

The material used was mainly palm wine (Figure 1) collected from three palm wine saleswomen on three different occasions in Djerègbé in the municipality of Sèmè-Podji. For each sampling, three samples were taken from each sales woman. On each occasion, the nine coded samples were transported to the laboratory in their original packaging (Figure 1) in a cooler containing cold accumulators for microbiological analysis. Thus, the nine samples consisting of the twenty seven samples were characterized microbiologically. The samples coming from point of sale $\mathrm{N}^{\circ} 1$ were coded $\mathrm{A} 1$, those coming from point of sale $\mathrm{N}^{\circ} 2$ were coded $\mathrm{A} 2$ while the samples coming from point of sale $\mathrm{N}^{\circ} 3$ were coded A3.

\section{Study Methods}

\section{Microbiological analyses}

\section{Preparation of culture media}

Culture media are natural and/or synthetic products composed of substances and elements essential for the optimal development of microorganisms under welldefined physico-chemical conditions. Each medium is used to search for specific microorganisms. Thus, the culture media are prepared according to the manufacturer's instructions. A precise quantity of the medium is weighed and mixed with a given quantity of distilled water.

The mixture is then slowly heated under stirring with a hot plate until a homogeneous suspension is obtained. This suspension is sterilized at $121^{\circ} \mathrm{C}$ for $15 \mathrm{~min}$ in the autoclave. Note that not all media have to be sterilized. This is the case, for example, with VRBL (Violet Red Bile Lactose). 
Preparation of the initial suspension and decimal dilutions

The initial suspension is the dilution from which the other successive dilutions are made. These dilutions can be done mass/mass or volume/volume. For example, $10 \mathrm{~g}$ of the sample is weighed aseptically into a sterile Stomacher bag. To this quantity is added $90 \mathrm{~g}$ of Tryptone Salt (TS) broth. The mixture is crushed and homogenized according to the nature of the sample.

The resulting solution is called initial suspension or initial solution. From this suspension, decimal dilutions are made. Thus, $1 \mathrm{ml}$ of the initial suspension is taken from a tube containing $9 \mathrm{ml}$ of sterile TS broth. The whole is homogenized giving the first decimal dilution. This operation is then repeated as many times as possible to obtain the desired dilution.

\section{Research and counting of germs}

The germs sought and enumerated were Total Mesophilic Aerobic Flora, total coliforms, Anaerobic Sulfito-Reducing (ASR) Bacteria, Escherichia coli, yeasts and molds, coagulase-positive staphylococci and lactic bacteria. These germs are searched for according to the methods described below:

\section{Counting of the total mesophilic aerobic flora (NF EN ISO 4833, 2006)}

$1 \mathrm{ml}$ of the selected dilutions is taken and introduced into different sterile Petri dishes. Then, $15 \mathrm{ml}$ of Plate Count Agar (PCA) is poured into the plates and gently homogenized and allowed to solidify. The Petri dishes are re-poured with about $5 \mathrm{ml}$ of the same agar to make the double layer. The incubation of the Petri dishes after solidification is done at $30^{\circ} \mathrm{C}$ for $72 \mathrm{~h} \pm 2 \mathrm{~h}$ and we proceed to colony counting.
Counting of coliforms (NF V 08-050, 2010 and NF V 08-060, 2010)

$1 \mathrm{ml}$ of the retained dilutions is taken and placed in sterile Petri dishes. Then, $15 \mathrm{ml}$ of VRBL (Violet Red Bile Lactose) agar is poured in and the whole is homogenized gently and allowed to solidify. After solidification, about $5 \mathrm{ml}$ of the same agar is re-cast to make the double layer.

This second layer of agar is left to solidify. Petri dishes are incubated at $30^{\circ} \mathrm{C}$ for total coliform count and at $44^{\circ} \mathrm{C}$ for thermotolerant coliform count for 24 hours \pm 2 hours. Colonies characteristic of coliforms are purplish-red in.

\section{Search for Anaerobic Sulfito-Reducing Bacteria (NF V 08-061, 2009)}

$1 \mathrm{ml}$ of the two successive dilutions selected is taken and introduced into two sterile screw cap tubes. Next, $15 \mathrm{ml}$ of Tryptone Sulfite Neomycin Agar (TSN) is poured into the tubes and homogenized gently to avoid bubbles forming in the tube. After solidification, the tubes are poured again with about $5 \mathrm{ml}$ of the same agar to create anaerobiosis. Both tubes are incubated at $46^{\circ} \mathrm{C}$ for $20 \mathrm{~h} \pm 2 \mathrm{~h}$. The presence of ASR results in the appearance of black colonies in the agar.

\section{Counting of Escherichia coli $\beta$ - glucuronidase-positive (NF ISO 16649-2, 2001)}

The process is the same as for coliforms except that the agar used is Tryptone Bile $\mathrm{X}$ $\beta$-glucuronide (TBX) without making the second layer. Incubation is done at $44^{\circ} \mathrm{C}$ for $24 \mathrm{~h} \pm 2 \mathrm{~h}$. On TBX, we obtain blue colonies. The search for $E$. coli from the coliform dishes (VRBL) is done by carrying out the Mackenzie test (indole and oxidase). 


\section{Indole test}

A of thermo-tolerant coliform colony is introduced into a sterile hemolysis tube containing $3 \mathrm{ml}$ of EPS (Sterile Peptone Water) and homogenized. Incubation is carried out at $37^{\circ} \mathrm{C}$ for $21 \pm 3$ hours. Then a few drops of Kovacs reagents are added. The positive result is the formation of a brownmahogany colored ring on the surface of the suspension. A greenish ring color reflects a negative result.

\section{Oxidase test}

This test is carried out according to the following steps:

Have an oxidase disc or blotting paper impregnated with the oxidase reagent;

Using a glass Pasteur pipette, take a part of the suspect colony and crush it on the disc or paper.

The positive result is manifested by a purple coloration, otherwise it is colorless.

\section{Counting of yeasts and molds (NF V 08- 059, 2006)}

$1 \mathrm{ml}$ of the selected dilutions is taken and introduced into different sterile petri dishes. Then $20 \mathrm{ml}$ of glucose agar enriched with oxy-tetracycline (OGA) is added. The whole is homogenized and allowed to solidify. The plates are incubated at $25^{\circ} \mathrm{C}$ for 3 to 5 days. The molds are filamentous while the yeasts have a milky appearance.

\section{Counting of coagulase-positive staphylococci (NF 08-057-1, 2004)}

Petri dishes are first cast with about $20 \mathrm{ml}$ of Baird Parker (BP) agar enriched with potassium tellurite egg yolk $(5 \mathrm{ml}$ of potassium tellurite enriched egg yolk per 100 $\mathrm{ml} \mathrm{BP}$ ). After solidification, $1 \mathrm{ml}$ of the retained dilutions is then removed and placed on the BP agar plates.

Subsequently, streak seedings on the surface of BP agar are performed. Incubation is done at $37^{\circ} \mathrm{C}$ for $48 \mathrm{~h} \pm 2 \mathrm{~h}$. The characteristic colonies of Staphylococcus on BP are black with or without a white halo. From its results, coagulase and catalase are searched.

\section{Research of catalase}

We place a drop of oxygenated water on a sterile slide and a part of the characteristic colony taken from the BP medium is triturated. The positive result is manifested by effervescence or air bubbles indicating catalase-positive staphylococci.

\section{Research of coagulase}

According to the standard used, three characteristic colonies and three isolated noncharacteristic colonies are targeted on Baird Parker agar. A portion of each is then inoculated respectively into approximately 3 $\mathrm{ml}$ of the heart-brain broth contained in a sterile hemolysis tube. The resulting bacterial suspension is incubated at $37^{\circ} \mathrm{C}$ for $22 \mathrm{~h} \pm 2 \mathrm{~h}$. After incubation, we add $0.3 \mathrm{ml}$ of rabbit plasma to $0.1 \mathrm{ml}$ of the bacterial suspension. The whole is incubated at $37^{\circ} \mathrm{C}$ for 5 to 19 hours. The positive reaction is manifested by a mass at the bottom of the tube. The reaction is negative when the medium remains fluid.

\section{Counting of lactic bacteria (NF ISO 15214,} 1998)

$1 \mathrm{ml}$ of the selected dilutions is taken and introduced in sterile petri dishes. Then $15 \mathrm{ml}$ of MRS (Man RogosaSharpe) agar is poured into the plates and the whole is gently homogenized and allowed to solidify. After solidification, about $5 \mathrm{ml}$ of the same agar is re-poured again to make the double layer. 
This second layer of agar is left to solidify. Petri dishes are incubated at $30^{\circ} \mathrm{C}$ for 3 days.

\section{Interpretation of microbiological results}

The results of the microbiological analyses obtained were interpreted according to the 3 class plan:

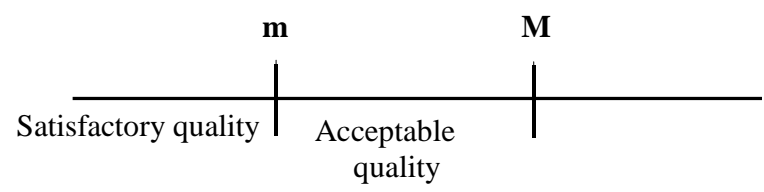

$\mathrm{m}=$ criteria such that results that are equal or inferior are considered to be incompliance (satisfactory quality);

$\mathrm{M}=$ threshold of acceptability above which results are not acceptable (unsatisfactory quality);

Results between $\mathrm{m}$ and $\mathrm{M}$ are considered conforming (acceptable quality).

\section{Statistical analysis}

The data collected was analyzed using SPSS version 16 software, which allowed for the analysis of variance (ANOVA) and Tukey's test for comparison of means. The significance level used was $5 \%$.

\section{Results and Discussion}

The results of the microbiological analyses performed on the palm wine samples taken in Djérègbé are presented in Table 1.

The analysis of Table 1 shows that the palm wine samples analyzed (A1 and A3), contained higher microbial loads (3 $10^{6} \mathrm{CFU} / \mathrm{ml}$ ) for the total mesophilic aerobic flora than that set by the standard $\left(10^{6} \mathrm{CFU} / \mathrm{ml}\right)$; in contrast to the microbial load of the A2 sample $\left(4.210^{5} \mathrm{CFU} / \mathrm{ml}\right)$. This can be explained by the lack of hygiene in the production environment as pointed out by Bayoï et al., (2014) who showed that the high microbial load of total germs encountered in fruit juices comes from the sociogeographical environment of manufacture and/or sale and the increased unhealthiness of the production sites which would be at the origin of ambient air pollution. Also, we noted that the samples (A1 and A3) analyzed, contained high microbial loads for yeasts (1.5 $10^{5} \mathrm{CFU} / \mathrm{ml}$ ) exceeding the limit value set by the standard $\left(10^{5} \mathrm{CFU} / \mathrm{ml}\right)$; contrary to the microbial load $\left(2.410^{4} \mathrm{CFU} / \mathrm{ml}\right)$ of the A2 sample. On the other hand, the microbial loads of all three samples were below the limit value $\left(10^{5} \mathrm{CFU} / \mathrm{ml}\right)$ for mold.

The microbial load of the yeasts and molds obtained in the samples may be explained by inappropriate storage of the wines as pointed out by Bayoï et al (2014). The latter showed that the abundance of yeasts and molds in the juices could be explained by failure to comply with hygiene rules during extraction, packaging and storage. Total coliforms and Escherichia coli were found in the samples analyzed. Total coliforms loads were superior at the set limit values $\left(10^{4} \mathrm{CFU} / \mathrm{ml}\right)$. The presence of these germs in the samples indicates contamination of fecal origin. This contamination may come from the environment as noted out by Houansou (2012).

In addition, the absence of Anaerobic SulfitoReducing bacteria and coagulase-positive staphylococci in the analyzed samples testifies to the respect of the rules of hygiene by the operator during the extraction as underlined by Agblonon-Houelome (2005).

Finally, the samples (A1 and A3) analyzed, contained high microbial loads in lactic bacteria $\left(310^{5} \mathrm{CFU} / \mathrm{ml}\right)$ than the limit value fixed by the standard $\left(10^{5} \mathrm{CFU} / \mathrm{ml}\right)$. 
Table.1 Microbiological characteristics of palm wine samples collected in Djerègbé

\begin{tabular}{|l|c|c|c|c|}
\hline $\begin{array}{l}\text { Settings } \\
\text { sought (CFU/ml) }\end{array}$ & A1 & A2 & A3 & $\begin{array}{c}\text { Canadian Standard } \\
\text { Criteria and Regulation } \\
\mathbf{2 0 7 3 / 2 0 0 5 / C E} \text { (CFU/ml) }\end{array}$ \\
\hline FAMT & $310^{6}$ & $4.210^{5}$ & $3.10^{6}$ & $\mathbf{1 0}^{\mathbf{6}}$ \\
\hline Laticbacteria & $310^{5}$ & $1.610^{4}$ & $3.10^{5}$ & $\mathbf{1 0}^{\mathbf{5}}$ \\
\hline Total coliforms & $310^{4}$ & $2.610^{2}$ & $3.10^{4}$ & $\mathbf{1 0}^{\mathbf{4}}$ \\
\hline Escherichia coli & $1.210^{2}$ & 60 & 50 & $\mathbf{1 0}^{\mathbf{3}}$ \\
\hline Coag Staphylococci (+) & $\mathrm{Abs}$ & $\mathrm{Abs}$ & $\mathrm{Abs}$ & Abs \\
\hline Bacteria ASR & $\mathrm{Abs}$ & $\mathrm{Abs}$ & $\mathrm{Abs}$ & $\mathbf{A b s}$ \\
\hline Yeast & $1.510^{5}$ & $2.410^{4}$ & $1.510^{5}$ & $\mathbf{1 0}^{\mathbf{5}}$ \\
\hline Mold & $10^{3}$ & $10^{3}$ & $210^{3}$ & $\mathbf{1 0}^{\mathbf{5}}$ \\
\hline
\end{tabular}

FAMT: Total Mesophilic Aerobic Flora;

A1: Samples from wind point $\mathrm{N}^{\circ} 1$; A2: Samples from wind point $\mathrm{N}^{\circ}$ 2; A3: Samples from wind point $\mathrm{N}^{\circ} 3$

Fig.1 Pictures of the palm wine

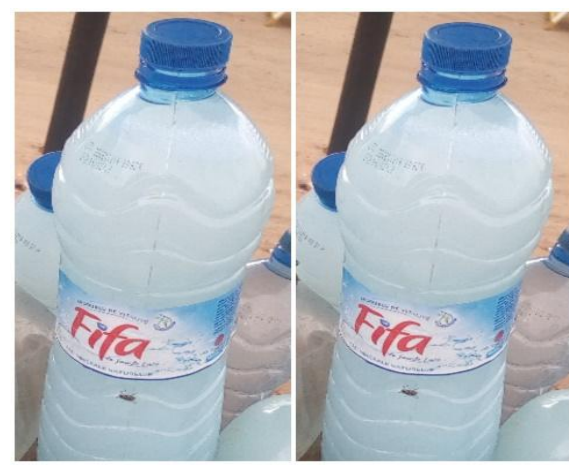

The palm wine samples analyzed (A1 and A3) are of unsatisfactory hygienic quality and the A2 sample is of satisfactory hygienic quality.

In conclusion the finally, the results of our study showed that two of the palm wine samples taken in Djèrègbé are of unsatisfactory hygienic quality. This is mainly due to the non-respect of the hygiene rules during the extraction of the palm wine by the producers on the one hand and during the packaging of the wine by the saleswomen on the other hand. The consumers of the palm wine sold in Djèrègbé are exposed to the risk of Food Poisoning.

\section{Conflict of interest}

The authors declare no conflict of interest, financial or otherwise.

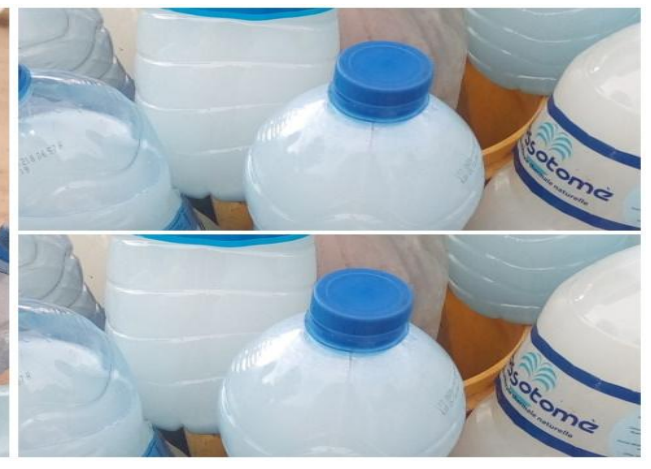

References

Adande A., and Adjanonhou G. 2010. Contribution à la stabilisation du vin de palme par la méthode de couplage filtration-pasteurisation. Rapport de fin d'étude pour l'obtention du diplôme de Licence en Génie des Technologies Alimentaires (GTA), Ecole Polytechnique d'Abomey-Calavi (EPAC), Université d'Abomey-Calavi (UAC), Bénin, 70p.

Agblonon Houelome E. 2005. Etude de la qualité microbiologique du jus d'ananas fabriqué au centre de séchage des fruits tropicaux d'Abomey. Mémoire pour l'obtention de la Maitrise professionnelle de Biotechnologie dans 
les industries agroalimentaires, Faculté des Sciences et Techniques (FAST), Université d'Abomey-Calavi (UAC), Bénin, 66p.

Bayoï J. R., Djoulde D. R., Maiwore J., Bakary D., Soppe Essome J., Noura B., Tcheme G., Tchio Sah R., Essia Ngang J., and Etoa F. 2014. Influence du procédé de fabrication sur la qualité microbiologique du jus de «foléré» (hibiscus sabdariffa) vendu dans trois villes du cameroun: Maroua, Mokolo et Mora. International Journal of Innovation and Applied Studies, 9(2): 786-796.

Béhit Y. E. N., Mollet M., Girardin O., Sorg J-P., and Herzog F., 2002. Le vin de palme, aliment et source de revenu pour les populations rurales en Côte d'Ivoire, Schweiz Z. Forstwes, 153 (2002) 4: 123-129..

Boni G., Beguin D., and Herzog F. 1994.Le palmier à huile. Sempervira. 50p.

Dessouassi O. 2013. Stabilisation du vin de palme par pasteurisation-adjonction d'huiles essentielles extraites des feuilles de Cymbopogon citratus (Citronnelle) et de Pimenta racemosa (Laurier). Mémoire de Licence, GTA, EPAC/UAC, Bénin, 73p.

Dornier M., Gerbaudo Y., and Bennarsar M. 1993. Clarification et stabilisation du vin de palme par filtration tangentielle sur membranes minérales: étude des conditions opératoires, in Industries agricoles alimentaires (Massy, France), vol. 110, n $11-2$, pp. 25-34.

Houansou G. D., 2012. Evaluation de la qualité et du risque sanitaire probable des aliments consommés lors des transports routiers: cas de l'axe Cotonou-Parakou. Mémoire pour l'obtention du diplôme du Master, à la FAST/UAC, Bénin, 33p.

Comité sur l'élaboration des critères microbiologiques dans les aliments (CECMA), 2006. Lignes directrices et normes pour l'interprétation des résultats analytiques en microbiologie alimentaire (Québec), 63p.

NF V 08-061, 2009. Dénombrement en anaérobiose des bactéries sulfitoréductrices par comptage des colonies à $46^{\circ} \mathrm{C}, 17 \mathrm{p}$.

NF V 08-050, 2010. Microbiologie des aliments-Dénombrement des coliformes présumés par comptage des colonies obtenues à $30^{\circ} \mathrm{C}, 12 \mathrm{p}$.

NF ISO 16649-2, 2001. Méthode horizontale pour le dénombrement des Escherichia coli bêta-glucuronidase positive-Partie 2: Technique de comptage des colonies à $44^{\circ} \mathrm{C}$ au moyen de 5 -bromo-4-chloro3-indolyl bêta-D-glucuronate, $11 \mathrm{p}$.

NF V 08-059, 2002. Dénombrement des levures et moisissures-Technique par comptage des colonies à $25^{\circ} \mathrm{C}, 19 \mathrm{p}$.

NF 08-057-1, 2004. Microbiologie des aliments-Méthode de routine pour le dénombrement des staphylocoques à coagulase positive par comptage des colonies à $37^{\circ} \mathrm{C}$ - Partie 1: technique avec confirmation des colonies, $21 \mathrm{p}$.

NF ISO 15214, 1998. Microbiologie des aliments - Méthode horizontale pour le dénombrement des bactéries lactiques mésophiles - Technique par comptage des colonies à 30 degrés Celsius, 13p.

NF EN ISO 4833-1, 2006. Microbiologie des aliments-Méthode horizontale pour le dénombrement des micro-organismesPartie 1: comptage des colonies à $30^{\circ} \mathrm{C}$ par la technique d'ensemencement en profondeur, 20p.

Règlement (CE) n²073/2005 de la Commission du 15 novembre 2005 concernant les critères microbiologiques applicables aux denrées alimentaires, $36 \mathrm{p}$. 


\section{How to cite this article:}

Tchekessi, C. K. C., A. K. E. Hilla, A. M. A. Djogbe, S. A. P. Sachi, S. Kouglenou, A. H. Loko, S. B. J. Banon, T. M. R. Bleoussi, T. K. Assogba and Bokossa Yaou, P. I. 2020. Evaluation of the Microbiological Quality of Palm Wine Sold in Djèrègbé on the CotonouPorto-Novo Road. Int.J.Curr.Microbiol.App.Sci. 9(10): 3908-3915. doi: https://doi.org/10.20546/ijcmas.2020.910.450 